\title{
Varietal Survey for Pigeon Pea Phytopthora Wilt in Kalaburgi District of Karnataka, India
}

\author{
Sureshbabu $^{1 *}$, Prasanna Sakhare ${ }^{1}$ and B. Zaheer Ahamed ${ }^{2}$ \\ ${ }^{1}$ College of Agriculture, Kalaburagi-585101, University of Agricultural Sciences, \\ Raichur, Karnataka, India \\ ${ }^{2}$ Krishi Vigyan Kendra, Kalaburagi-585101, University of Agricultural Sciences, \\ Raichur, Karnataka, India \\ *Corresponding author
}

\begin{tabular}{|c|c|}
\hline \multicolumn{2}{|r|}{ A B S T R A C T } \\
\hline & \multirow{6}{*}{$\begin{array}{l}\text { To assess the severity of the wet wilt problem, survey for the wilt disease was } \\
\text { undertaken in Kharif } 2016 \text { at Kalaburgi district of Karnataka. The information } \\
\text { were collected reveals that incidence of wilt ranged from } 1 \text { to } 15 \text { per cent and } \\
\text { mean incidence of } 6.0 \text { per cent were recorded. Among the variety cultivated were } \\
\text { checked for the disease incidence, the Local Gulyal, Double moong, Katti beeja } \\
\text { are shown symptoms of phytopthora wilt and stem canker disease. These all the } \\
\text { varieties were inspected under the rainfed situations, wherever the crop and soil } \\
\text { zone wet situations the incidence of wilt was observed. The high incidence is } \\
\text { noticed in Sedam and Chittapur taluks } 3 \text { to } 14 \text { and } 3 \text { to } 15 \text { range respectively. The } \\
\text { Jewargi and Alanda taluk the incidence varied from } 2 \text { to } 9 \text { and } 2 \text { to } 11 \% \text { range } \\
\text { respectively. }\end{array}$} \\
\hline & \\
\hline $\begin{array}{l}\text { Incidence, Kharif, } \\
\text { Pigeonpea, Wilt. }\end{array}$ & \\
\hline Article Info & \\
\hline $\begin{array}{l}\text { Accepted: } \\
\text { 15 October } 2017 \\
\text { Available Online: } \\
10 \text { December } 2017\end{array}$ & \\
\hline & \\
\hline
\end{tabular}

\section{Introduction}

Pigeon pea, Cajanus cajan (L) Millsp is the second most important pulse crop in India after chickpea. It has multiple uses and occupies an important place in the revailing farming systems in the country and vegetarian diet. It also plays an important role in sustainable agriculture by enriching the soil through biological nitrogen fixation along with deep root system of this crop which makes it more suitable for its cultivation under rainfed conditions. District Kalaburgi of Karnataka occupies 3.75 lakh hectares of land with average productivity of $560 \mathrm{~kg} \mathrm{ha}^{-1}$ of pigeon pea. In order to make the nation self-sufficient in pulses productivity levels of pulses need to be increased substantially from $560 \mathrm{~kg} \mathrm{ha}^{-1}$ to $1,200 \mathrm{~kg} \mathrm{ha}^{-1}$ by 2020 (Ali and Kumar, 2005). Faulty sowing practices, improper crop geometry, avoid use of biofertilizers, Trichoderma, other intercultural operations and climatic variabilities are predominant reasons for limiting the potential yield of pigeonpea Major cause of low productivity is the losses due to isease. Among disease, wilt and sterility mosaic disease are important. Recent surveys have indicated that major losses in the pigeonpea are due to wilts and losses varying from 0.2 to 
100 per cent have been estimated in India (Gade, 2002).

The disease is known in India with description of wilt of pigeon pea by Butler (1906). Though the disease goes unnoticed in early stages, the symptom of water soaked lesions, withering and drying drooping of leaves and finally death of few branches of entire plant are the conspicuous symptoms of manifested during flowering or grain development.

If wilted plants are uprooted and longitudinally split, a clear black vascular browning is seen. Infection of plants in early stage leads to infection of roots, stem cortex and reaching up to vascular bundles where the pathogen multiplies and blocks water and nutrient flow to upper region which leads to yellowing and finally death of plant. In order to make in depth study of wilt in pigeonpea the present studies were undertaken.

\section{Materials and Methods}

A roving survey on Phytopthora wilt disease on pigenopea was done in three villages of every taluk which includes Kalaburgi, Sedam, Chittapur, Alanda, Jewargi, Chincholi taluks during late kharif of 2016.

The type of seed used, seed protection measures, NPK and Micronutrient application system, disease management technique and yield enhancing information were collected during the spot visit. The wilt $(\%)$ incidence was noted in every locations viz., the information was collected, tabulated, analysed.

The percent disease incidence of wilt was calculated by using the formula:

Number plants infected

Percent disease incidence $=$------------- $\times 100$

Total number of plant examined

Table.1 Phytopthora Wilt incidence in Kharif-2016 at Kalaburgi district

\begin{tabular}{|l|l|c|c|l|l|}
\hline $\begin{array}{l}\text { Sl } \\
\text { no. }\end{array}$ & Districts & $\begin{array}{c}\text { Wilt Incidence } \\
\text { range }\end{array}$ & $\begin{array}{c}\text { Incidence } \\
(\mathbf{\%})\end{array}$ & Variety & Cropping system \\
\hline 1 & Kalaburgi & $2-13$ & 6.5 & TS3R & Redgram +Bajra \\
\hline 2 & Chincholi & $1-12$ & 6.0 & Double moong & Redgram +Soybean \\
\hline 3 & Sedam & $3-14$ & 7.0 & Local Gulyal & Redgram \\
\hline 4 & Jewargi & $2-9$ & 4.5 & TS3R & Redgram \\
\hline 5 & Chittapur & $3-15$ & 7.5 & Katti Beeja & Redgram \\
\hline 6 & Aland & $2-11$ & 5.5 & TS3R & Redgram +Sesamum \\
\hline \multicolumn{2}{|l|}{ Average mean } & $1-15$ & 6.0 & - & - \\
\hline
\end{tabular}

\section{Results and Discussion}

A standard format was prepared for collection of information during survey. For survey work, approximately $10-12 \mathrm{~km}$ distance, a plot was selected where five lines of 20 meter length was selected randomly and count of the standing plants, were taken. Number of plants wilted, out of total plant stand was recorded. Additional information on name of variety, soil type and previous crop and cropping pattern were also noted. Results showed in Table 1 reveals that Phytopthora wilt of Redgram incidence in different taluks of Kalaburgi district of Karnataka varied. The cloud days, low temperature and Kharif season rain received in almost all black soil belt decides the incidence of disease. During the survey the cropping system, the variety used and time of sowing also taken into 
account. The disease incidence in Kalaburgi ranged for 2 to 13 and the TS3R is very popularly cultivated whereas in Chincholi the incidence ranged from 1 to $12 \%$. The high incidence is noticed in sedam and chittapur 3 to14 and 3 to 15 range. Jewargi and alanda taluk the incidence varied from 2 to 9 and 2 to 11 respectively.

Among the variety cultivated were checked for the disease incidence and Local Gulyal, Double moong, Katti beeja are shown symptoms phytopthora wilt and stem canker disease. These all the varieties were inspected under the rainfed situations, wherever the crop and soil zone wet situations the incidence of wilt was observed. The cropping system varied from location to location Redgram monocrop, Redgram with soybean, Redgram with sesamum and Redgram with Pearl millet Bajra cropping system is more observed during the survey. Most of the farmers using the last years seeds without proper seed protection measures. The present observations on incidence of wilt (\%) are in conformity with Kannaiyan and Nene (1981), Patil et al., (1990), Gade (2002) and Anonymous (2013).

\section{References}

Anonymous (2013). Area and production of pulses in India and Karnataka.Hindu Survey, pp: 102-104.

Butler, E.J. (1906). The wilt disease of pigeonpea and pepper. Agric. J. India. 1: 25-36.

Gade, R.M. (2002). Integrated disease management of pigeonpea wilt. Ph.D.Thesis, Marathwada Agricultural University, Parbhani, M.S. (INDIA).

Kannaiyan, J. and Nene Y.L., Reddy, M.V., Ryan, J.G., and Raju, T.N. (1984). Prevalence of pigeonpea diseases associated with crop losses in Asia. Africa and America. Trop. Pest Manag., 30(1): 62-71.

Patil, P.V., Patil B.P.and Karandikar, V.R. (1990). Studies on wilt disease of pigeonpea with reference to yield losses and varietal reaction. Proceed. Indian Phytopath.Soc., 34: 17.

Raj, A. D., Yadav, V. and Rathod, J.H. (2013) Impact of front line demonstration (FLD) on the yield of pulses. International J. Sci. and Res. 9(3): 1-4.

\section{How to cite this article:}

Sureshbabu, Prasanna Sakhare and Zaheer Ahamed, B. 2017. Varietal Survey for Pigeon Pea Phytopthora Wilt in Kalaburgi District of Karnataka, India. Int.J.Curr.Microbiol.App.Sci. 6(12): 1831-1833. doi: https://doi.org/10.20546/ijcmas.2017.612.207 